J. Lake Sci.(湖泊科学), 2016, 28(2):379-386

DOI 10. 18307/2016. 0218

(c) 2016 by Journal of Lake Sciences

\title{
湖南沅水五强溪水库鱼类资源现状及其历史变化
}

向 鹏, 刘良国**, 王 冬, 曾平文, 邓玲玲,杨春英,杨品红

(湖南文理学院生命科学学院, 湖南省水产高效健康生产协同创新中心, 动物学湖南省高校重点实验室, 常德 415000)

\begin{abstract}
摘 要: 水电工程对鱼类生境和资源多样性具有重大的影响. 于 2012 年 4 月-2014 年 3 月, 对湖南省沅水五强溪水库鱼 类资源进行调查, 以了解五强溪水库建成 20 年后鱼类资源的现状及多样性变化. 结果表明, 在五强溪水库共采集鉴定鱼 类 86 种 (包括引进种 5 种), 隶属 7 目 18 科 58 属. 种类组成以鲤形目种类数最多, 占总种类数的 $66.28 \%$. 在五强溪水库 库尾、库区和坝下江段, 鱼类物种数分别为 $54 、 67$ 和 52 , 其中, 库区与坝下江段之间鱼类群落为中等相似, 库区与库尾、库 尾与坝下江段之间鱼类群落为中等不相似. 在生态类型上, 水库鱼类呈现多样化特征, 以湖泊定居性、杂食性和底栖性鱼 类居多, 分别占总种类数的 $68.60 \% 、 55.81 \%$ 和 $41.86 \%$. 各江段渔获物组成存在一定差异, 但黄颡鱼 (Pelteobagrus fulvidraco)、鲤(Cyprinuscarpio)、鲫(Carassius auratus)、蒙古鲌(Culter mongolicus) 等在各江段均占有较高比例. 渔获物产量 和规格以库区较高, 库尾、坝下江段偏低, 鱼类小型化现象明显. 与五强溪水库建成前相比, 本次调查水库库区江段鱼类 种类减少 46 种, 降幅为 $40.71 \%$, 一些常见经济鱼类如鳤( Ochetobius elongatus)、白甲鱼( Onychostoma sima)、瓣结鱼(Brevifilis brevifilis)、长吻鮠( Leiocassis longirostris) 等没有发现.
\end{abstract}

关键词: 沅水;五强溪水库; 鱼类资源;生态类型; 渔获物

\section{Status and historical changes of fish resources of Wuqiangxi Reservoir on Yuanshui River in Hunan Province}

\author{
XIANG Peng, LIU Liangguo**, WANG Dong, ZENG Pingwen, DENG Lingling, YANG Chunying \& \\ YANG Pinhong \\ (Key Laboratory of Zoology in Hunan Higher Education, Collaborative Innovation Center for Efficient and Health Production \\ of Fisheries in Hunan Province, College of Life Science, Hunan University of Arts and Science, Changde 415000, P.R. China)
}

\begin{abstract}
Hydropower development had a significant effect on the fish habitat and their biological diversity. To evaluating the current status and changes of fishery resource of Wuqiangxi Reservoir 20 years after the completion of a hydroelectric dam, the fish resources were investigated during April of 2012 to March of 2014. Results showed that a total of 86 fish species (including 5 introduced) were collected, belonging to 7 orders, 18 family, 58 genera. Cypriniformes were dominant, accounting for $66.28 \%$ of the total species. There were 54, 67 and 52 fish species found in the end, reservoir and downstream reach of Wuqiangxi Reservoir, respectively. The jaccard similarity coefficient showed that the fish communities of the reservoir area were highly similar to those at the dam sector, and moderately dissimilar to those at the reservoir tail. It was also the same moderately dissimilar between the reservoir tail and the dam sector. With regard to ecological type, fish communities in the Wuqiangxi Reservoir showed diversification types, the sedentary, omnivore and demersa species were dominant, accounting for $68.60 \%, 55.81 \%$ and $41.86 \%$ of the total species, respectively. Despite the species of the catches in various sections were different, the species number such as Pelteobagrus fulvidraco, Carassius auratus, Cyprinuscarpio and Culter mongolicus occupied a higher proportion in each section. The yield and dimension of the reservoir area were higher than those of the other two sections, and the catches showed miniaturization significantly. We compared the fish species number of the reservoir area between the pre- and post-dam periods, the fish species reduced 46 species and dropped $40.71 \%$. Some common economic fishes such as Ochetobius elongatus, Onychostoma sima, Brevifilis brevifilis and Leiocassis longirostris were not found.
\end{abstract}

* 国家自然科学基金项目 (31572619) 和湖南省高校创新平台基金项目 (13K103) 联合资助. $2015-03-22$ 收稿; 2015-06-24 收修改稿. 向鹏( 1992 ), 男, 硕士研究生;E-mail: xp518@ foxmail.com.

** 通信作者;E-mail: llg1818@126.com. 
Keywords: Yuanshui River; Wuqiangxi Reservoir; fish resources; ecological type; fish catches

水电建设带来社会经济效益的同时,对河流生态系统也带来重大影响. 水电工程建设运行后, 江段被 分割为 “河流-水库-河流”形式, 天然河流的连续性遭到破坏,库区和坝下江段的水文情势都将发生很大的变 化,主要体现在径流量、水位、流速、水质、泥沙、温度等因素的改变,进而对所在生境中的生物产生影响,尤 其对鱼类影响较大,鱼类的区系组成、资源数量、遗传多样性及繁殖策略等都会发生重大变化 ${ }^{[1-6]}$.

五强溪水电站是长江中游洞庭湖分支水系——沅水的最大水利工程, 建成于 1994 年, 是沅水流域水电 梯级开发的骨干电厂. 五强溪水库 $\left(28^{\circ} 15^{\prime} \sim 28^{\circ} 48^{\prime} \mathrm{N}, 110^{\circ} 10^{\prime} \sim 111^{\circ} 04^{\prime} \mathrm{E}\right)$ 位于湖南省沅陵县境内的沅水干 流上, 控制流域面积 $83800 \mathrm{~km}^{2}$, 占沅水流域面积的 $93 \%$, 坝址多年平均流量 $2040 \mathrm{~m}^{3} / \mathrm{s}$, 年径流量 $643 \times 10^{8} \mathrm{~m}^{3}$. 水库最大坝高 $85.83 \mathrm{~m}$, 正常蓄水位 $108 \mathrm{~m}$, 水库面积 $170 \mathrm{~km}^{2}$, 干流回水长度 $150.2 \mathrm{~km}^{[7]}$. 五强溪未成水库 库区时, 邓中粦等 ${ }^{[8]}$ 根据 1989 年沅水鱼类资源调查结果, 报道了沅水鱼类区系组成、水库库区及坝下江段 渔业资源状况和产飘流性卵鱼类的繁殖状况, 并就五强溪水利工程对沅水鱼类资源的影响进行了预测. 时 隔 20 年, 五强溪水库鱼类资源现状如何? 鱼类区系组成和资源多样性发生了哪些变化? 目前还缺少这方 面的研究报道. 本文通过对五强溪水库的鱼类资源调查, 旨在了解水库建成运行 20 年后鱼类资源的现状及 多样性变化,为长江中游分支河流梯级开发影响下的鱼类资源可持续发展和保护提供参考.

\section{1 材料与方法}

\section{1 调查方法}

2012 年 4 月- 2014 年 3 月,对五强溪水库分春季 ( 4 月)、夏季 ( 7 月)、秋季 (10 月)、冬季( 1 月)进行 2 年共 8 次鱼类资源调查. 调查区域包括五强溪水库库尾至坝下江段凌津滩水库坝址之间干流河段 (图 1), 具体调查分为 3 个区段: 水库库尾 (辰溪县城至沾溪县城河段)、水库库区 (沪溪县城至五强溪电站坝址河 段) 和坝下江段 (五强溪电站坝址至凌津滩电站坝址河段), 每个区段每次调查 $10 \mathrm{~d}$.

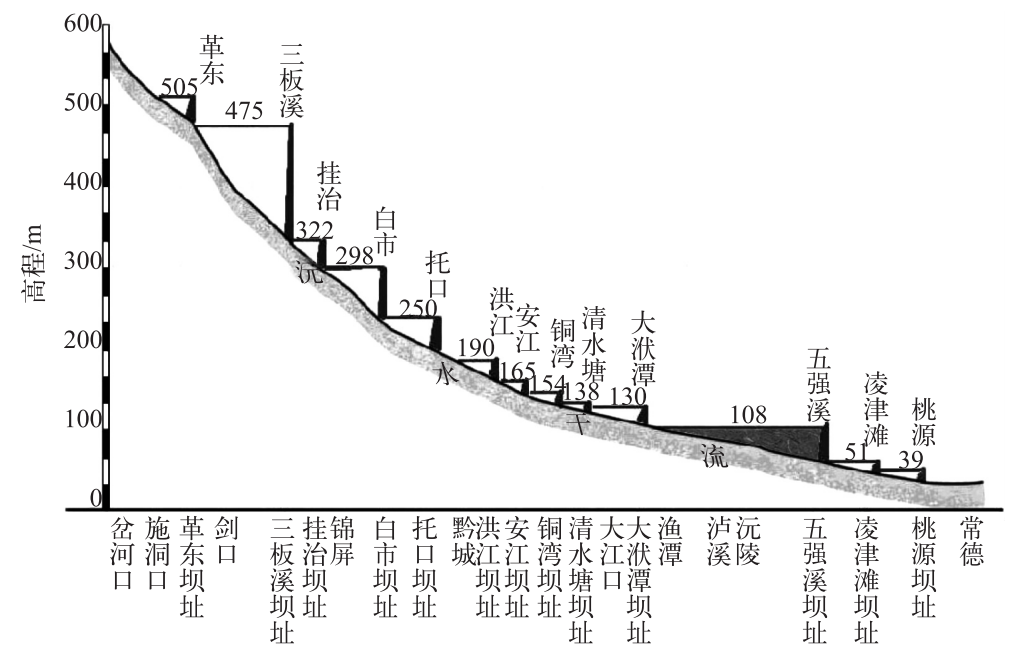

图 1 五强溪水库在沅水梯级中的位置

Fig.1 Location of Wuqiangxi Reservoir among cascade hydropower stations of Yuanshui River

依照《内陆水域渔业自然资源调查手册》 ${ }^{[9]}$, 采取自捕、雇请渔民捕捞或与渔民协商约定对其捕获物进 行统计、码头和市场渔获物统计等调查方式. 调查渔具以刺网 (网目规格分别为 $120 、 80 、 40$ 和 $20 \mathrm{~mm}$ ) 为主, 结合拖网 (网目规格分别为 20 和 $10 \mathrm{~mm}$ )、钓钩、虾笼、电鱼机等. 对采集的鱼类标本进行现场拍照、分类、 记数、体长、体重测量, 不易确定的种类用 $10 \%$ 的福尔马林溶液保存带回实验室鉴定. 标本鉴定及分类主要 依据《中国动物志 - 硬骨鱼纲 - 鲤形目 (中卷) 》 ${ }^{[10]}$ 、《中国动物志 $\cdot$ 硬骨鱼纲・ 鲤形目 (下卷) 》 ${ }^{[11]}$ 、《中国 
动物志 - 硬骨鱼纲 - 鲇形目 $\rangle^{[12]}$ 和《中国淡水鱼类检索》 ${ }^{[13]}$. 所有标本整理编号, 保存于湖南文理学院洞庭 湖水系鱼类标本室.

另在五强溪水库库尾、库区及坝下江段设立渔获物调查点, 分夏、秋两季进行渔获物调查, 调查渔具为 定置刺网和拖网, 各江段取样季节、渔具种类数量和船次相同, 统计各江段主要经济鱼类在渔获物中的数量 和重量比例.

\section{2 鱼类多样性统计方法}

Jaccard 相似性系数 $q=c /(a+b-c)$. 式中, $a$ 为 $\mathrm{A}$ 群落的物种数, $b$ 为 $\mathrm{B}$ 群落的物种数, $c$ 为 $\mathrm{A} 、 \mathrm{~B}$ 群落共 有物种数. 当 $q$ 在 $0 \sim 0.25$ 之间时为极不相似; $0.25 \sim 0.50$ 为中等不相似; $0.50 \sim 0.75$ 为中等相似; $0.75 \sim$ 1.00 为极相似 ${ }^{[14]}$.

\section{2 结果与分析}

\section{1 种类组成}

在五强溪水库库尾、库区和坝下江段共采集鉴定鱼类 86 种,隶属 7 目 18 科 58 属,其中鲟形目 1 科 1 属 1 种、鲑形目 1 科 1 属 1 种、鲤形目 3 科 39 属 57 种、鲇形目 5 科 8 属 16 种、领针鱼目 1 科 1 属 1 种、合鳃目 1 科 1 属 1 种、鲇形目 6 科 7 属 9 种. 各目鱼类的分类统计信息见表 1 . 其中水库库尾 54 种,隶属 4 目 11 科 47 属; 水库库区 67 种, 隶属 7 目 15 科 51 属; 坝下江段 52 种, 隶属 3 目 8 科 43 属. 调查鱼类以鲤形目种类数最 多,占总种数的 $66.28 \%$,其次为鲇形目 $(18.60 \%)$ 和鲇形目 $(10.47 \%)$, 其它目的物种数仅 1 种. 在 86 种鱼 中,包含鸭嘴匙吻鲟、太湖新银鱼、丁鱥、斑点叉尾鮰、加州鲇 5 种引进种.

\section{2 各江段鱼类群落相似性}

对比五强溪水库库尾、库区和坝下江段鱼类物种相似度, 发现水库库尾与库区、库尾与坝下江段和库区 与坝下江段相同的鱼类物种数分别是 37,34 和 50 . Jaccard 相似性系数分析表明,水库库区与坝下江段之间 的鱼类群落相似性系数为 0.72 , 为中等相似; 水库库尾与库区、库尾与坝下江段的相似性系数分别为 0.44 、 0.47 , 为中等不相似.

五强溪水库 3 个相邻江段的鱼类群落相似性差异, 主要与不同江段的水域环境密切相关. 水库库尾江 段, 河道坡度相对较大, 水流急, 底质多砾石, 一些喜流水型或底栖生活的鱼类, 如沾溪直口鲮、长薄鲉、南方 鲉鮀、下司华吸䲝、中华纹胸鮡等主要分布于此区域, 湖泊定居性鱼类相对较少; 水库库区由于水体加深, 水 流变缓, 近似湖泊环境, 湖泊定居性鱼类相对较多; 坝下江段由于下泄水流冲击, 导致一些适应静水水体生

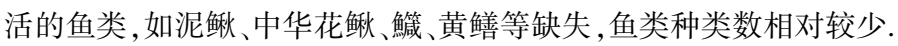

\section{3 生态类型}

根据不同的生活方式对五强溪水库鱼类生态类型进行分类 (表 1). 按照鱼类的生活习性并参考有关文 献 ${ }^{[15-17]}$, 可以将水库鱼类大致分为 3 个生态类群: (1) 河湖洄游性,包括鸭嘴匙吻鲟、青鱼、草鱼、鲢、鳙、鳡、 赤眼鳟、鳊、黄尾鲖、细鳞鲖、似鳊、铜鱼等 12 种, 占 $13.95 \%$; (2) 山溪流水性, 包括麦穗鱼、带半刺光唇鱼、吉

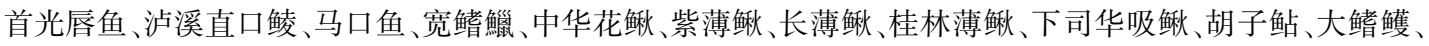
子陵吻鰕虎鱼等 14 种, 占 $16.28 \%$; (3) 湖泊定居性, 包括太湖新银鱼、鲫、鲤、鲇、粲属、鲌属、团头鲂、黄颖鱼 属等 60 种,占 $69.77 \%$.

根据鱼的胃内容物解剖, 并依据相关文献 ${ }^{[18]}$, 可以将水库鱼类大致分为杂食性、肉食性和植食性 3 种.

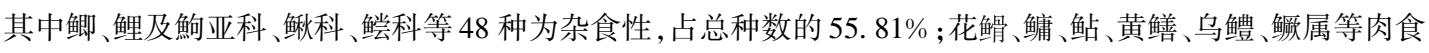
性鱼类 31 种,占 $36.05 \%$; 草鱼、鳊、鲢等植食性鱼类 7 种,占 $8.14 \%$.

参考相关文献 ${ }^{[19-20]}$, 按栖息水层可将五强溪水库鱼类大致分为中上层、中下层和底栖 3 种类型 . 其中 鲫、鲤、青鱼、鲀科、魭科等底栖鱼类 36 种,占总种数的 $41.86 \%$; 其次为粲属、银鮈、似鳊、鲌属、鲭属、鱊亚科、 鮨科、鲢、鱤、鳙等中上层鱼类 29 种,占 $33.72 \%$; 蛇鮈、草鱼、鳊、鲇、团头鲂等中下层鱼类 21 种, 占 $24.42 \%$.

\section{4 渔获物结构}

在五强溪水库的库尾、库区和坝下江段共统计刺网和拖网渔获物 60 船次 (各采样区域分别统计 20 船 次), 总计 $418.00 \mathrm{~kg}$. 对各江段渔获物进行分析 (表 2). 从渔获物的组成看, 黄滪鱼、鲤、鲫、蒙古鲌等鱼类在 
水库各江段均占较高比例, 粗唇鮠、大鳍鱯、沙塘鳢等底栖鱼类在水库库尾有较高比例, “四大家鱼”之一的 鳙因人工放流或网箱逃逸在水库库区有较大发展. 各调查江段渔获物的规格大小 (尾均重) 以库区较高, 库 尾和坝下江段偏低. 在渔获物组成中, 鲫、粲、黄颡鱼、银鮈等小型鱼类所占比例均较高. 除水库库区外, 经 济鱼类小型化现象也比较明显, 如鲤、蒙古鲌的尾均重在库尾江段仅分别为 $680.36 、 276.62 \mathrm{~g}$, 在坝下江段仅 分别为 $528.21 、 196.60 \mathrm{~g}$.

\section{表 1 五强溪水库鱼类名录、分布和生态类型}

Tab. 1 Taxa, distribution and ecological types of fishes in the Wuqiangxi Reservoir

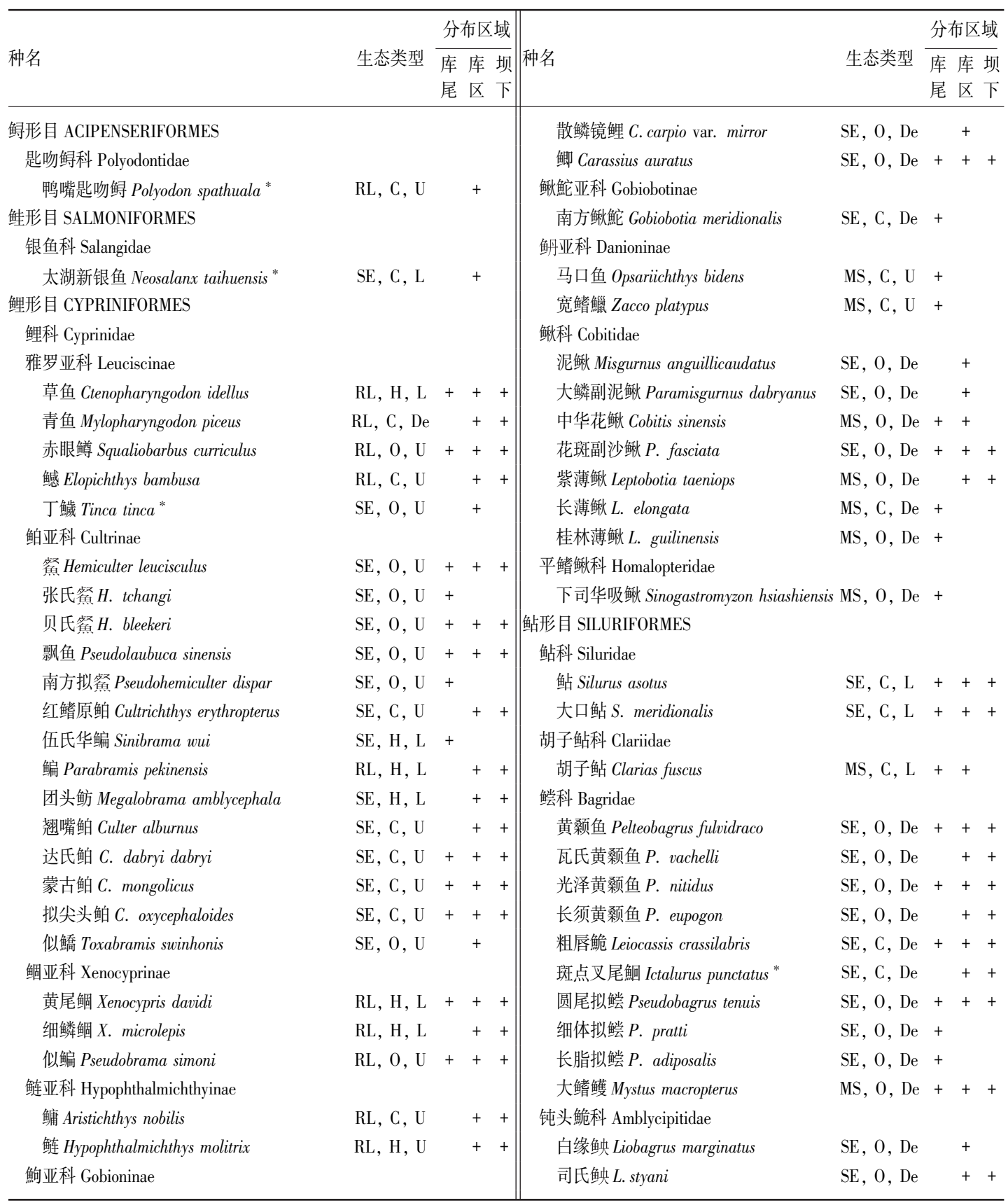




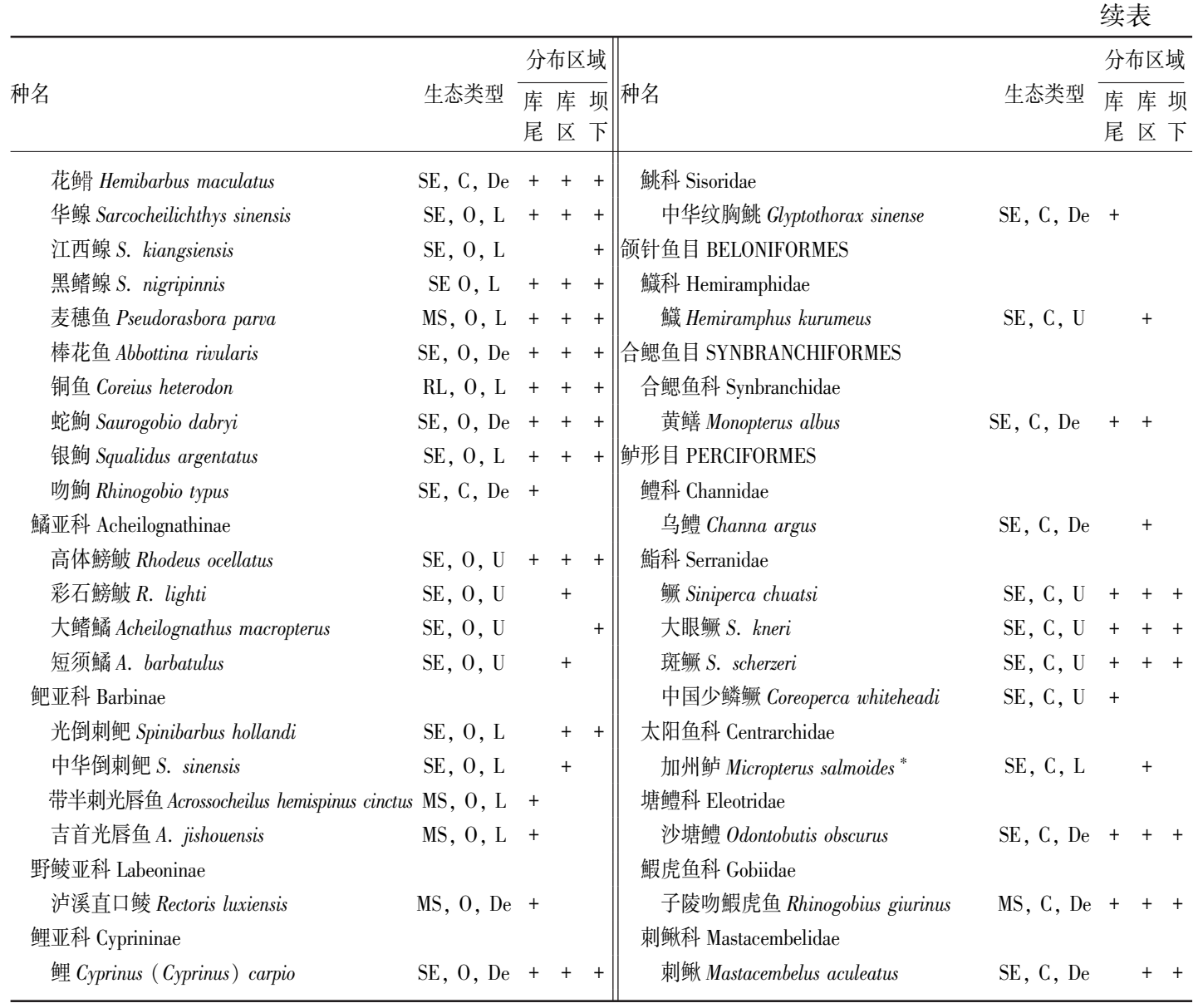

* 表示引进种; RL 表示河湖洄游性,SE 表示湖泊定居性, MS 表示山溪流水性; H 表示植食性, C 表示肉食性, $\mathrm{O}$ 表示杂食 性; $\mathrm{U}$ 表示中上层,L 表示中下层,De 表示底栖 .

\section{3 讨论}

\section{1 五强溪水库鱼类资源现状与历史变化}

通过对五强溪水库 3 个相邻江段鱼类资源的实地调查和标本鉴定, 五强溪水库现有鱼类 86 种, 其中包 括鸭嘴匙吻鲟、太湖新银鱼、丁鱥、斑点叉尾鮰、加州鲇 5 种引进种. 3 个相邻江段鱼类物种数以五强溪水库 库区最多 (67 种)、库尾 (54 种) 和坝下 (52 种) 江段较少, 其中, 鲤形目鱼类种数在库尾、库区和坝下江段分 别为 $36 、 42$ 和 35 种,占各自江段鱼类总数的 $66.67 \% 、 62.69 \%$ 和 $67.31 \%$. 本次调查水库库区鱼类种类数与 1989 年的调查记录 $(113 \text { 种 })^{[8]}$ 相比, 减少了 46 种, 降幅达 $40.71 \%$.

已有研究表明,鱼类的群落结构与栖息地不同水环境条件密切相关. Perera 等 ${ }^{[21]}$ 调查发现, 随着三峡 大坝的建成, 三峡库区鱼类区系由适应流水生存的种类转变为适应静水生存的种类. 刘春池等 ${ }^{[22]}$ 根据葛洲 坝水库鱼类生态类群分析, 发现静水缓流型鱼类是葛洲坝库区的主要鱼类,占总种数的 $71.0 \%$. 而一些适应 流水环境的鱼类多分布在水流流速较高的水库上游溪流和坝下江段 ${ }^{[23-24]}$. 五强溪水库建成蓄水后, 库区水 域生境由河流型向湖泊型转变, 坝下部分天然河道遭受破坏, 水库生境的变化不仅导致鱼类资源数量的减 少,鱼类区系组成也发生明显变化. 在水库库区,一些适应静水环境、耐低氧、适应性强的鱼类,如黄颡鱼 属、翅嘴鲌、蒙古鲌等有较高的资源量, 而一些适应原天然河流生境的土著鱼类, 如带半刺光唇鱼、沾溪直口 鲮、马口鱼、宽鳍鱲、下司华吸䲝等在库区几近消失,这些鱼类上溯至水库库尾及上游, 此次调查这些鱼类在 
库尾江段均有分布. 在坝下江段,一些适应穴居或喜栖淤泥生活的鱼类,如乌鳢、黄鳞、泥鱾等没有发现,而 像紫薄鲉、大鳍鱯、子陵吻鰕虎鱼等适应底栖流水生活的鱼类在该江段仍有分布, 这与大坝水流下泄, 坝下 干流仍为流水环境有关. 从生态类型上看, 五强溪水库鱼类以湖泊定居性鱼类为主, 其中水库库尾还分布 有一定种类的山溪流水性鱼类;一些生境和繁殖条件广适性鱼类, 如鲫、鲤、麦穗鱼、棒花鱼、蛇鮈、银鮈等在 水库库尾、库区和坝下江段均有分布,资源优势比较明显.

表 2 五强溪水库库尾、库区和坝下江段渔获物组成

Tab. 2 Composition of catches in the end, reservoir and downstream reaches of Wuqiangxi Reservoir

\begin{tabular}{|c|c|c|c|c|c|c|}
\hline 江段 & 种类 & 尾数 & 尾数比 $/ \%$ & 重量/g & 重量比/\% & 尾均重/g \\
\hline \multirow[t]{11}{*}{ 库尾 } & 黄颡鱼 & 398 & 14. 64 & 20650 & 16.52 & 51.90 \\
\hline & 蛇鮈 & 562 & 20.66 & 18600 & 14.88 & 33.12 \\
\hline & 鲤 & 24 & 0.90 & 16663 & 13.33 & 680.36 \\
\hline & 华鳊 & 228 & 8. 40 & 14225 & 11.38 & 62.33 \\
\hline & 鲇 & 73 & 2. 69 & 13063 & 10.45 & 178.44 \\
\hline & 鲫 & 240 & 8.82 & 11475 & 9.18 & 47.85 \\
\hline & 蒙古鲌 & 24 & 0.88 & 6625 & 5.30 & 276.62 \\
\hline & 大鯺鳠 & 88 & 3.23 & 4263 & 3.41 & 48.62 \\
\hline & 粗唇鮠 & 90 & 3. 33 & 4150 & 3.32 & 45.88 \\
\hline & 沙塘鳢 & 93 & 3.43 & 3750 & 3.00 & 40.26 \\
\hline & 其它 & 898 & 33.04 & 11538 & 9.23 & \\
\hline \multirow[t]{11}{*}{ 库区 } & 鳙 & 16 & 0.68 & 50589 & 24.38 & 3138.20 \\
\hline & 鲤 & 25 & 1. 05 & 25440 & 12. 26 & 1020.66 \\
\hline & 蒙古鲌 & 66 & 2. 78 & 20522 & 9.89 & 310.32 \\
\hline & 翅嘴鲌 & 29 & 1. 21 & 17928 & 8.64 & 625.87 \\
\hline & 鲫 & 340 & 14. 32 & 17015 & 8.20 & 50.00 \\
\hline & 大眼鳜 & 180 & 7. 58 & 14795 & 7. 13 & 82.10 \\
\hline & 粲 & 698 & 29.38 & 13799 & 6.65 & 19.77 \\
\hline & 黄颡鱼 & 201 & 8.46 & 11703 & 5.64 & 58.20 \\
\hline & 光泽黄颡鱼 & 395 & 16. 62 & 11350 & 5.47 & 28.75 \\
\hline & 瓦氏黄颡鱼 & 154 & 6.47 & 10479 & 5.05 & 68.14 \\
\hline & 其它 & 272 & 11. 45 & 13882 & 6.69 & \\
\hline \multirow[t]{11}{*}{ 坝下 } & 鲤 & 22 & 0.96 & 11628 & 13.60 & 528.21 \\
\hline & 鲫 & 228 & 9. 90 & 10388 & 12. 15 & 45.64 \\
\hline & 黄颡鱼 & 190 & 8.27 & 9277 & 10.85 & 48.79 \\
\hline & 鲇 & 47 & 2. 04 & 8105 & 9.48 & 172.76 \\
\hline & 翅嘴鲌 & 16 & 0.69 & 7507 & 8.78 & 475.48 \\
\hline & 蒙古鲌 & 36 & 1. 58 & 7148 & 8.36 & 196.60 \\
\hline & 银鮈 & 401 & 17. 44 & 6643 & 7.77 & 16.57 \\
\hline & 蛇鮈 & 202 & 8.80 & 6541 & 7.65 & 32.33 \\
\hline & 粲 & 340 & 14. 81 & 6524 & 7.63 & 19.16 \\
\hline & 子陵吻鰕虎鱼 & 505 & 21.96 & 4352 & 5.09 & 8.62 \\
\hline & 其它 & 312 & 13. 57 & 7387 & 8.64 & \\
\hline
\end{tabular}

与历史资料 ${ }^{[3]}$ 比较, 五强溪水库现有鱼类资源具有以下特点: 一是建库前曾报道出现的江海洄游性鱼 类鳗鳎和国家一级保护鱼类胭脂鱼, 本次调查已难寻踪迹; 二是一些过去在库区占有一定比例的经济鱼类, 如白甲鱼、鲩、湘华鲮 ( Sinilabeo tungting)、长吻鯔、瓣结鱼等此次调查未采获到。“四大家鱼” 特别是鲔、草鱼 在水库库区内虽有较大发展, 但这主要是人工养殖的结果; 三是在渔获物组成中, 以鲫、鲤、翅嘴鲌、蒙古鲌、 鲇、黄滪鱼、粲、蛇鮈、银鮈、大鯺鳠、子陵吻鰕虎鱼等湖泊定居性鱼类或山溪流水性鱼类为主,鳊、䱛、细鳞 
鲖、铜鱼等河湖洄游性鱼类所占比例极低. 经济鱼类产量和规格除水库库区较高外, 库尾和坝下江段均较 低,鱼类小型化现象明显, 主要表现为一些小型鱼类如鲫、粲、蛇鮈、银鮈、黄滪鱼等在渔获物中的比例高,一 些中型经济鱼类如鲤、尧嘴鲌、蒙古鲌等呈小型化趋势. 五强溪水库鱼类资源的变化, 除了过度捕捞、水域 污染、涉水活动等原因外, 大坝阻隔导致的水域生态环境改变是鱼类资源变化的重要原因. 大坝直接阻断 了鱼类的洄游通道, 原天然河道流水性环境转变成湖泊静水性环境, 导致一些繁殖需流水环境、产漂流性卵 鱼类资源数量在水库库区的减少甚至消失, 如白甲鱼、鳤等; 而一些栖息地需要依赖流水条件或底质砂石生 活的鱼类, 则在库区基本消失或种类数量极少, 一些种类迁移至水库库尾或上游支流, 如湘华鲮、长吻鯔、瓣 结鱼、大鯺鱯、沾溪直口鲮、马口鱼等. 水库库区经济鱼类产量和规格较高, 与库区水体的营养化程度较高 密切相关. 此外, 一些外来鱼种如斑点叉尾鮰、太湖新银鱼在水库库区有发展形成优势种群之势.

\section{2 鱼类资源保护}

沅水是长江的第 3 大支流, 沅水流域属亚热带季风气候区, 流域水量充沛, 分支水系发达, 饵料资源丰 富, 水域生态环境适合鱼类生长, 因而鱼类资源丰富. 沅水鱼类资源对长江水系鱼类资源多样性的维持或 补充有着重要意义. 然而, 近一、二十年来, 沅水干流上一系列梯级电站, 特别是像五强溪等大型水库的建 设运行, 极大地改变了河流生态环境, 对沅水水生生物尤其是鱼类的生存和繁衍产生重要的影响. 从本次 五强溪水库的鱼类资源调查结果来看, 鱼类的种类数量、渔获物组成和物种多样性都已发生很大的变化. 因此, 针对性地开展沅水梯级开发影响下的鱼类资源保护, 可以采取以下一些方法措施: (1) 开展人工增殖 放流. 鱼类人工增殖放流是主动增殖水生生物资源、修复水域生态、特别是增加洄游性和流水性鱼类资源 量的有效手段。近些年来, 在沅水的不同江段包括五强溪水库, “四大家鱼” 的人工增殖放流一直在进行, 并 取得了很好的增殖效果, 如在五强溪水库库区的渔获物中, 鳙和草鱼就占有较大比例. 沅水其它一些洄游 性或流水性珍稀鱼类如鲩、鳡、白甲鱼、瓣结鱼、长吻鮸等的人工增殖研究与放流工作也亟需引起重视 . (2) 加强鱼类繁殖保护, 强化禁渔期管理. 保护鱼类繁殖群体是鱼类种群数量增长、鱼类资源恢复的重要一环. 在规定的禁渔期内严禁捕捞作业, 严禁捕捞产卵亲鱼、保护生殖群体, 严禁捕捉在潕水、辰水、武水、西水、渠 水、巫水和溆水等各支流河口索饵的经济鱼类的幼鱼,使它们能正常生长发育, 从而有利于沅江中下游洄游 性或流水性鱼类资源的恢复. (3) 建立沅水土著鱼类资源自然保护区. 在五强溪水库上游支流, 可以选择水 质较好、人为干扰较少的江段, 建立鱼类资源自然保护区, 重点对受五强溪水电工程影响, 而迁移至上游支 流的一些流水性生活土著鱼类如带半刺光唇鱼、马口鱼、宽鳍鱲、沾溪直口鲮、长薄䲝、下司华吸鳅等进行 保护.

致谢: 感谢沅陵县环境保护局杨献中、沅陵县水库移民管理局邓壮河在鱼类资源调查过程中提供的帮助.

\section{4 参考文献}

[1] 蒋 红, 谢嗣光, 赵文谦等. 二滩水电站水库形成后鱼类种类组成的演变. 水生生物学报, $2007,31(4)$ : 532-539.

[ 2 ] Patrick M. Silenced Rivers: The ecology and politics of large dams. Enlarged and updated edition. London: Zed Books Ltd, 2001.

[ 3 ] Barrella W, Petrere MJ. Fish community alterations due to pollution and damming in Tiete and Paranapanema rivers(Brazil). River Reseach and Applications, 2003, 19(1): 59-76.

[ 4 ] Merona B, Vigouroux R, Tejerina-Garro FL. Alteration of fish diversity downstream from Petit-Saut Dam in French Guiana. Implication of ecological strategies of fish species. Hydrobiologia, 2005, 551: 33-47.

[ 5 ] 危起伟, 陈细华, 杨德国等. 葛洲坝截流 24 年来中华鲟产卵群体结构的变化. 中国水产科学, 2005, 12(4): $452-457$.

[ 6 ] Qiao Y, Tang X, Brosse S et al. Chinese sturgeon(Acipenser sinensis) in the Yangtze River, a hydroacoustic assessment of fish location and abundance on the last spawning ground. Journal of Applied Ichthyology, 2006, 22(Suppl. 1) : 140-144.

[ 7 ] 罗郧红. 五强溪水库建库前后水质变化分析. 四川水力发电, 2009, 28(5): 82-87.

[ 8 ] 邓中粦, 蔡明艳, 陈景星. 五强溪水利工程对沅江鱼类资源的影响. 淡水渔业, 1992, 4: 12-16.

[ 9 ] 张觉民, 何志辉. 内陆水域渔业自然资源调查手册. 北京: 中国农业出版社, 1991: 242-298. 
[10］陈宜瑜. 中国动物志・硬骨鱼纲・鲤形目(中卷). 北京: 科学出版社, 1998: 1-531.

[11］乐佩琦. 中国动物志 ·硬骨鱼纲・鲤形目(下卷). 北京: 科学出版社, 2000: 1-661.

［12］褚新洛, 郑葆珊, 戴定远等. 中国动物志・硬骨鱼纲・鲇形目. 北京: 科学出版社, 1999: 1-200.

[13] 朱松泉. 中国淡水鱼类检索. 南京: 江苏科学技术出版社, 1995: 1-549.

[14] 陈小华, 李小平, 程 瞨. 黄浦江和苏州河上游鱼类多样性组成的时空特征. 生物多样性, 2008, 16(2): 191-196.

[15] 茹辉军, 刘学勤, 黄向荣等. 大型通江湖泊洞庭湖的鱼类物种多样性及其时空变化. 湖泊科学, 2008, 20(1): 93-99. DOI 10.18307/2008.0114.

[16] 湖北省水生生物研究所鱼类研究室. 长江鱼类. 北京: 科学出版社, 1976.

[17] 胡茂林, 吴志强, 刘引兰. 鄱阳湖湖口水域鱼类群落结构及种类多样性. 湖泊科学, 2011, 23(2) : 246-250. DOI 10.18307/2011.0213.

[18］叶富良, 张健东. 鱼类生态学. 广州: 广东高等教育出版社, 2002: 56-57.

[19] 茹辉军, 王海军, 赵伟华等. 黄河干流鱼类群落特征及其历史变化. 生物多样性, 2010, 18(2): 179-186.

[20] 李 捷, 李新辉, 谭细畅等. 广东肇庆西江珍稀鱼类省级自然保护区鱼类多样性. 湖泊科学, 2008, 20(1):9399. DOI $10.18307 / 2009.0415$.

[21] Perera HA, Li ZJ, Silva SS et al. Effect of the distance from the dam on river fish community structure and compositional trends, with reference to the Three Gorges Dam, Yangtze River, China. Acta Hydrobiologicca Sinica, 2014, 38 (3): 438-445.

[22] 刘春池, 高 欣, 林鹏程等. 葛洲坝水库鱼类群落结构特征研究. 长江流域资源与环境, 2012, 21(7): 843-849.

[23] Marchetti MP, Moyle PB. Effects of flow regime on fish assemblages in a regulated California stream. Ecological Applications, 2001, 11(2) : 530-539.

[24] 林鹏程, 高 欣, 刘春池等. 葛洲坝上下游江段鱼类时空分布特征研究. 长江流域资源与环境, 2011, 20(9): 1047-1053. 